\title{
Construction of a full bacterial artificial chromosome (BAC) library of Oryza sativa genome
}

\author{
TAO Quanzhou*, Haiying ZHAO*, Longfang QIU*, \\ Guofan $\mathrm{HONG}^{* * 1}$. \\ *National Center for Gene Research, Chinese Academy of \\ Sciences, Shanghai 200233, China \\ ** Shanghai Institute of Biochemistry, Chinese Academy \\ of Sciences, Shanghai 200031, China.
}

\begin{abstract}
We have constructed a full BAC library for the superior early indica variety of Oryza sativa, Guang Lu Ai 4. The MAX Efficiency DH10B with increased stability of inserts was used as BAC host cells. The potent pBelo BACII with double selection markers was used as cloning vector. The cloning efficiency we have reached was as high as $98 \%$, and the transformation efficiency was raised up to $10^{6}$ transformants / $\mu \mathrm{g}$ of large fragment DNA. The BAC recombinant transformants were picked at random and analyzed for the size of inserts, which turned out to be of $120 \mathrm{~kb}$ in length on average. We have obtained more than 20,000 such BAC clones. According to conventional probability equation, they covered the entire rice genome of $420,000 \mathrm{~kb}$ in length. The entire length of inserts of the library obtained has the 5- to 6 - fold coverage of the genome. To our knowledge, this is the first reported full BAC library for a complex genome.
\end{abstract}

Key words: bacterial artificial chromosome, indica, Oryza sativa, library.

\section{INTRODUCTION}

1. Corresponding author.

Abbreviations: BAC, bacterial artificial chromosome; SOB medium ( without magnesium ): Bacto-tryptone $20 \mathrm{~g}$, Bacto-yeast extract $5 \mathrm{~g}, \mathrm{NaCl}, 0.584 \mathrm{~g}, \mathrm{KCl} 0.186 \mathrm{~g}$, distilled water to $1 \mathrm{~L}$; WB, $10 \%$ ultra pure glycerol, $90 \%$ distilled water, v/v; SOC medium:SOB medium with $0.02 \mathrm{M} \mathrm{Mg}^{2+}$ and $0.02 \mathrm{M}$ glucose; pFGE, pulsed -field gel electrophoresis. 
The sheer size of the rice genome is the major impediment to the construction of a comprehensive physical map. The need to rapidly clone, map and manipulate large DNA molecules has become acute in conjunction with the rice genome project. Yeast artificial chromosomes ( YACs ) [1,2] are currently the major technology being employed in the mapping of complex genomes, such as those of human and rice. The major problem with YAC cloning system is its high frequency of in vivo recombination. The BAC cloning system[3] offers advantages over the YAC cloning system in three important areas. First, it is possible to prepare BAC libraries that contain very few chimeric clones. Second, it is possible to stably propagate in BAC certain DNA sequences that cause instability and rearrangements in YAC vectors. Third, the isolation and analysis of BAC clones are substantially easier and faster. Adoption of BAC cloning system would thus be expected to achieve significant savings of time and money, associated with the mapping and analysis of complex genomes.

\section{MATERIALS AND METHODS}

\section{Materials}

14 days old rice, indica variety Guang Lu Ai 4 ( provided by China National Rice Research Institute, Hang Zhou), growing in green house. Host cell, E. Coli strain DH10B (genotype: F-merA $\triangle($ mrr-hsdRMS-mcrBC) $\Phi 80$ dlacZ $\triangle$ M15 $\triangle$ lacX74 deoR racA1 endA1 araD139 $\triangle($ ara, Ieu $) 7697$ gaIU gaIK $\lambda$ rpsL nupG) with high stability of inserts was obtained from GIBCO. Vector pBeloBACII ( unpublished ) was from Dr. M. Simon, Division of biology, California Institute of Technology, Pasadena, CA, USA, through Dr. Hongbin Zhang of Taxes A\&M University. pBeloBAC II is a $\mathrm{F}$ factor vector, with chloramphenicol resistance gene and lacZ gene as selection markers, and unique restriction site, HindIII, among others, as cloning site. $\beta$-agarose (DNase free) was from New English Biolabs, Hind III, NotI, lysozyme, T4 DNA ligase, proteinase K, sucrose ( molecular biology grade ) were from Boehringer Mannheim. Agarose ( ultra pure DNA grade, molecular biology certified ) from BioRad Laboratories. Pulsed-gel electrophoresis system, chef mapper, including high volt power supply, pulsed-field gel electrophoresis unit, cooling unit, and pulse control unit was purchased from BioRad. Electroporator( with cuvettes), a Cell-Porator E.coli system, was from BRL.

\section{Preparation of large DNA fragments from plant nuclei and digestion of DNA embedded in agarose}

Rice leaves were used as materials for the preparation of large DNA fragments by the modification of the method[4-8]. The tissues can be either frozen in liquid nitrogen and stored in a $-70^{\circ} \mathrm{C}$ freezer or kept fresh on ice before use. The reagents used in the preparation were the following. $10 \times$ homogenization buffer (HB) stock: $0.1 M$ Trizma base, $0.8 M \mathrm{KCl}, 0.1 M$ EDTA, 10 $\mathrm{mM}$ sepermidine, $10 \mathrm{mM}$ spermine, final $\mathrm{pH}$ 9.4-9.5 adjusted with $\mathrm{NaOH}$. The stock is stored at $4^{\circ} \mathrm{C}$. $1 \times \mathrm{HB}$ : a suitable amount of sucrose is mixed with a suitable volume of $10 \times \mathrm{HB}$ stock. The final concentration of sucrose is $0.5 M$ and HB stock is $1 \mathrm{x}$. The resultant $1 \times \mathrm{HB}$ is stored at $4^{\circ} \mathrm{C}$. Before use, $\beta$-mercaptoethanol is added to $0.15 \%$. Wash buffer $(1 \times \mathrm{HB}$ plus $0.5 \%$ Triton $\mathrm{X}-100)$ is prepared by mixing $1 \times \mathrm{HB}$ without $\beta$-mercaptoethanol with TritonX-100 and stored at $4^{\circ} \mathrm{C}$. Before use, $\beta$-mercaptoethanol is added to $0.15 \%$. Lysis buffer: 0.5M EDTA, pH 9.0-9.3, $1 \%$ sodium lauryl sarcosine, and $0.1 \mathrm{mg} / \mathrm{ml}$ protienase $\mathrm{K}$. The proteinase $\mathrm{K}$ powder is added just before use.

Grind about $25 \mathrm{~g}$ of the frozen tissue into powder in liquid nitrogen with a mortar and pestle and immediately transfer into an ice-cold $500 \mathrm{ml}$ beaker containing $200 \mathrm{ml}$ ice-cold $1 \times \mathrm{HB}$ plus 


\section{Tao QZ et al.}

$\beta$ - mercaptoethanol and $0.5 \%$ Triton X-100. Gently swirl the contents with a magnetic stir bar for 10 min. on ice and filter into an ice-cold $250 \mathrm{ml}$ centrifuge bottle. Pellet the homogenate prepared by the above method by centrifugation with a fixed-angle rotor at $1,800 \mathrm{~g}$ at $4{ }^{\circ} \mathrm{C}$ for $20 \mathrm{~min}$. Discard the supernatant fluid and add approximately $1 \mathrm{ml}$ of ice-cold wash buffer. Gently resuspend the pellet with assistance of a small paint brush soaked in ice-cold wash buffer and finally, add an additional $30 \mathrm{ml}$ of the ice-cold wash buffer. In order to remove the particulate matter remaining in the suspension, filter the resuspended nuclei into a $50 \mathrm{ml}$ centrifuge tube through two layers of gauze by gravity. Centrifuge the contents at $570 \mathrm{~g}, 4{ }^{\circ} \mathrm{C}$ for $2 \mathrm{~min}$ to remove intact cells and tissue residues. Transfer the supernatant fluid into a fresh centrifuge tube and pellet the nuclei by centrifugation at $1,800 \mathrm{~g}, 4{ }^{\circ} \mathrm{C}$ for $15 \mathrm{~min}$. in a swinging bucket centrifuge. Wash the pellet 1-2 additional times by resuspension in wash buffer followed by centrifugation at $1,800 \mathrm{~g}, 4^{\circ} \mathrm{C}$ for $15 \mathrm{~min}$. After the final wash, resuspend the pelted nuclei in a small amount ( about $1 \mathrm{ml}$ ) of $1 \times \mathrm{HB}$ without $\beta$-mercaptoethanol, and store on ice. In order to embed the nuclei in agarose plugs, prewarm the nuclei to $45^{\circ} \mathrm{C}$ in a water bath ( about 5 min ) before being embedded in agarose. Mix the nuclei with an equal volume of $1 \%$ low-melting point agarose in $1 \times \mathrm{HB}$ without $\beta$-mercaptoethanol using a Pipetman. The agarose should be melted in boiling water and kept at $42^{\circ} \mathrm{C}$ before use. Aliquot the mixture into ice-cold plug molds on ice with the same Pipetman ( $100 \mu \mathrm{l} / \mathrm{plug}$ ). When the agarose is completely solidified, transfer the plugs into 5-10 volumes of lysis buffer. Incubate the agarose plugs in the lysis buffer for $24-48 \mathrm{~h}$ at $50^{\circ} \mathrm{C}$ with gentle shaking. Wash the plugs once in 0.5 $M$ EDTA, pH 9.0-9.3 for $1 \mathrm{~h}$ at $50^{\circ} \mathrm{C}$, once in $0.05 \mathrm{M}$ EDTA, $\mathrm{pH} 8.0$ for 1 $\mathrm{h}$ on ice, and store in $0.05 \mathrm{M}$ EDTA, $\mathrm{pH} 8.0$ at $4^{\circ} \mathrm{C}$. Before digestion of DNA embedded in agarose, wash the plugs containing high molecular weight DNAs three times in 10-20 volumes of ice-cold TE ( $10 \mathrm{mM}$ Tris-HCI, $\mathrm{pH}$ 8.0, $1 \mathrm{mM}$ EDTA, $\mathrm{pH} 8.0$ ) plus $0.1 \mathrm{mM}$ phenylmethyl sulfonyl fluoride (PMSF) and three times in 10-20 volumes of ice cold TE on ice, $1 \mathrm{~h} /$ each wash. For digestion of agarose plugs, mix the followings in a sterile microcentrifuge tube: Water $31 \mu \mathrm{l}$, agarose plugs of about $50 \mu \mathrm{l}, 10 \times$ enzyme buffer $10 \mu \mathrm{l}$ and $40 \mathrm{mM}$ spermidine $5 \mu \mathrm{l}$. After incubation on ice for 1 $\mathrm{h}$, add $4 \mu \mathrm{l}$ ( approximately $10 \mathrm{units} / \mu \mathrm{g}$ DNA ) of restriction enzyme - HindIII was used in this work - for complete digestion and add $4 \mu \mathrm{l}$ of each of enzyme dilution series for partial digestion. Incubate on ice for additional 30 min to allow the enzyme to access to the DNA in the agarose and then transfer the reaction mixture to the recommended temperature for enzyme activity. For complete digestion, incubate the reaction mixture for at least $3 \mathrm{~h}$. For partial digestion, incubate the agarose plugs for $1 \mathrm{~h}$. Stop the reaction by adding 1/10 volume of $0.5 M$ EDTA, pH 8.0. Load the digested high molecular weight DNA in agarose plugs into the well of an agarose gel for PFGE and seal in position with the same agarose as the gel. Set the PFGE program for the best resolution of the DNA ranging from 100-200 kb[9]. After electrophoresis, DNA ranging about 120 to $150 \mathrm{~kb}$ was excised from low-melting agarose gel. The agarose slice was dialysed in 3 to 5 volume of TNE $(10 \mathrm{~m} M$ Tris, $1 \mathrm{mM}$ EDTA, $50 \mathrm{mM} \mathrm{NaCl}, \mathrm{pH} 7.5)$ at $4^{\circ} \mathrm{C}$ for at least $1 \mathrm{~h}$ and processed to ligation step. For Southern blotting, stain the gel in ethidium bromide for $1 \mathrm{~h}$, destain for a couple of hours, photograph, and nick the DNA in the gel with $60 \mathrm{~mJ}$ Joules of UV light ( $254 \mathrm{~nm}$ ). Blot the DNA in the gel onto Hybond- $\mathrm{N}^{+}$membrane (Amersham, USA ) with $1.5 \mathrm{M} \mathrm{NaCl}, 0.4 \mathrm{M} \mathrm{NaOH}$ for 40 h. When finished the blotting, take out the membrane, and wash it in $2 \times \mathrm{SSC}$ for 10 min with gentle shaking. The membrane can be directly used for Southern blot hybridization or wrapped with Handy Wrap and stored at $4^{\circ} \mathrm{C}$.

\section{Ligation and electroporation}

After dialysis, the low melting point agarose slices were melted at $68^{\circ} \mathrm{C}$ for $10-15 \mathrm{~min}$. Then transfer the tube containing the melted agarose into $40^{\circ} \mathrm{C}$ bath. Add $1 / 10$ vol. of $10 \times$ agarose buffer (100 mM Bis-Tris-HCl, $10 \mathrm{mM}$ EDTA pH6.5) prewarmed at $40^{\circ} \mathrm{C}$ and $1 \mu \mathrm{l}$ agarose $(1 \mu)$ per $100 \mu \mathrm{l}$ of melted agarose. The mixture was incubated at $40^{\circ} \mathrm{C}$ for $1-2 \mathrm{~h}$. One to three hundred nanograms of the rice DNA was ligated to Hind III digested pBeloBAC II (molar ratio of 6 to 1 in pBeloBAC II excess) with T4 DNA ligase at $16^{\circ} \mathrm{C}$. overnight[10]. DH10B cells suitable for 


\section{Representative BAC library of rice genome}

high-efficiency transformation by electroporation[11] can be prepared from log-phase cultures by washing the cells twice and resuspending them at a high cell density (about $1 \times 10^{6} \mathrm{cell} / \mathrm{s} / \mathrm{ml}$ ) in $10 \%$ glycerol. The transformation efficiency ( transformants/ $\mu$ g DNA ) in our experiment was about $10^{6}$. The detailed procedures were as follows. Use a fresh colony of cells to inoculate $50 \mathrm{ml}$ of SOC medium. Grow cells with vigorous aeration overnight at $37{ }^{\circ} \mathrm{C}$. Dilute $0.5 \mathrm{ml}$ of cells into $500 \mathrm{ml}$ of SOC medium in a 2.8-L flask. Grow for 2 to $3 \mathrm{~h}$ with vigorous aeration at $37^{\circ} \mathrm{C}$ until $\mathrm{OD}_{500}=0.8$. Harvest cells by centrifuging at $5,000 \mathrm{rpm}(2,600 \times \mathrm{g})$ for $10 \mathrm{~min}$. Wash the cell pellet by resuspending in $500 \mathrm{ml}$ of sterilized, ice-cold WB. Centrifuge the cell suspension at 5,000 rpm $(2,600 \times \mathrm{g})$ for $15 \mathrm{~min}$ and carefully pour off the supernatant as soon as the rotor stops. Wash the cell pellet once again as above. Resuspend the cell pellet in WB to a final density of 200 to 250 $\mathrm{OD}_{550}$ units ( about 1 to $2 \mathrm{ml}$ ). Usually, no additional WB needs to be added to the cell pellet, it can be resuspended in the WB that remains in the centrifuge bottle. Cells can be used immediately or can be frozen in $200 \mu \mathrm{l}$ aliquots in microcentrifuge tubes using a dry ice-ethanol bath. Store frozen cells at $-70{ }^{\circ} \mathrm{C}$. Aliquot $20 \mu \mathrm{l}$ samples of cells ( not frozen ) into sterilized microcentrifuge tubes. Add $1 \mu \mathrm{l}$ of ligated DNA, and mix with the pipette tip. Use a micropipetter to suspend each cell-DNA sample between the electrode bosses of a Disposable Micro-Electroporation Chamber, and perform electroporation. Extra care in the preparation of DNA for high-voltage electroporation into the host cell will improve both transformation efficiency and consistency. For preparing DNA from ligation reactions, to a $20 \mu \mathrm{l}$ ligation mixture, add $2 \mu \mathrm{l}$ of $3 \mathrm{M}$ sodium acetate ( $\mathrm{pH} 7.0$ ), and mix. Add $44 \mu \mathrm{l}$ of $95 \%$ ethanol, and mix. Centrifuge for $15 \mathrm{~min}$ at room temperature at $12,000 \times \mathrm{g}$ in the microcentrifuge. Remove the supernatant, add $60 \mu \mathrm{l}$ of $70 \%$ ethanol, and centrifuge for $15 \mathrm{~min}$, Remove the supernatant. Dry the pellet, and resuspend the pellet in $20 \mu \mathrm{l}$ of $0.5 \times \mathrm{TE}$. Triansfer the resuspended DNA to a new microfuge tube, and add to cells. With the VOLTAGE RANGE selector switch on the $E$. coil, set Pulser ta MEDIUM ( about $2.5 \mathrm{kV}$ ), the fixed capacitance of 2 $\mu \mathrm{F}$, and internal parallel resistance of $4 \mathrm{k} \Omega$, the host cell-DNA mixtures yielded consistently high transformation efficiencies of around $10^{6}$ transformants/ $\mu \mathrm{g}$ DNA.

We have also embedded the nuclei in agarose microbeads and digested the DNA in them. The results were satisfactory.

\section{RESULTS}

We have obtained more than $2 \times 10^{4}$ BAC clones which constitute our rice genome library. The digestion of the BAC DNA with NotI to completion was performed in the usual way[5], except that the incubation at $37{ }^{\circ} \mathrm{C}$ lasted at least for $3 \mathrm{~h}$, and extra incubation at $65{ }^{\circ} \mathrm{C}$ for $10 \mathrm{~min}$ was made before loading. For the better resolution for DNA fragments ranging from 10 to $350 \mathrm{~kb}$, we chose the CHEF MAPPER of BioRad, and set the working conditions as follows: $1 \%$ agarose, $0.5 \times \mathrm{TBE}$, initial 5 seconds, final 15 seconds, angle $120^{\circ}, 6 \mathrm{v} / \mathrm{cm}, 12^{\circ} \mathrm{C}, 18 \mathrm{~h}$ and linear.

Fig A showed the analysis of rice BAC library constructed in this work. 19 BAC clones were picked up at random, and the DNAs prepared from them wcre digested with NotI to completion. Lambda ladder and lambda / HindIII digest were on the both side of the gel as molecular markers. Lambda ladders were prepared from lambda by joining their cohesive ends at random, which resulted in concatemers. The BAC inserts were shown to contain various number of NotI sites. The common bands in all lanes except the marker lanes were the vector DNA, which were released from the two unique NotI sites located in the polylinker at the either side of the ihsert. Lane 1 to 19 were the complete NotI digests of the BAC clones. It can be seen from the figure that the average size of the inserts was of $120 \mathrm{~kb}$ in length. 
Tao QZ et al.

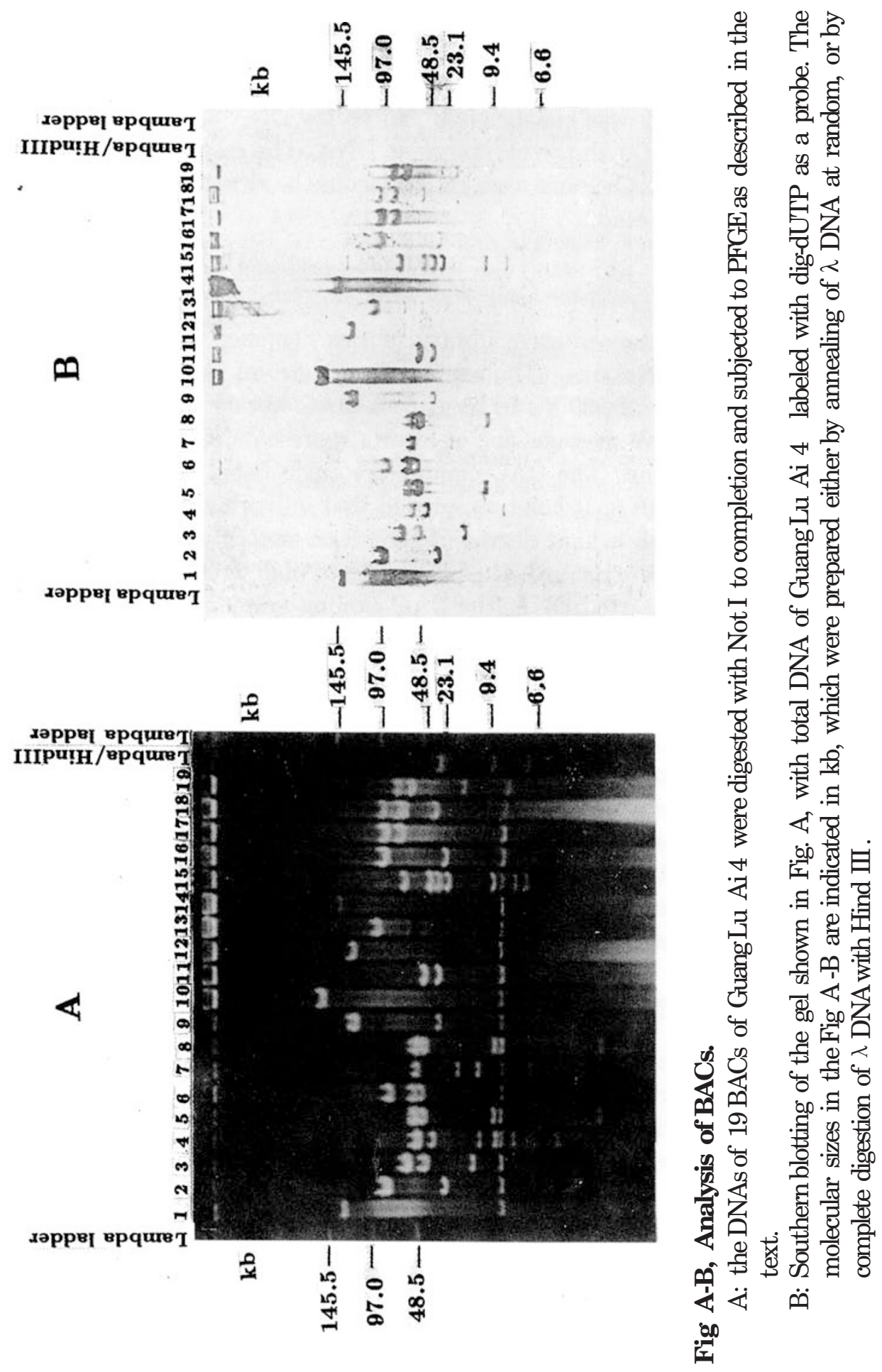


Representative BAC library of rice genome

Fig B showed the Southern blotting with digoxigenin-dUTP randomly labeled chromosome DNA as probe against the complete digest of the same BAC clones as those shown in Fig A. It can be seen from the figure that all the inserts released from the the clones were hybridized with the labeled Guang Lu Ai 4 chromosome DNA from which the BAC library was constructed. No vector DNA and marker DNAs were shown to be hybridized with the chromosome DNA. The result clearly showed that all the inserts of the $\mathrm{BAC}$ clones were coming from the rice chromosome, from which the BAC library was made.

\section{DISCUSSION}

For construction of a representative library of rice genome, the BAC cloning system was obviously an ideal one. The average insert size of BAC recombinants constructed in this lab was of $120 \mathrm{~kb}$ in length. A BAC library containing $1.6 \times$ $10^{4}$ recombinants with above average size of inserts represents $99 \%$ of probability of covering the entire genome. The BAC cloning system is capable of maintaining large fragments of foreign DNA. It has been proved that individual clones of foreign DNAs were maintained with a high degree of structural stability in the host cell, even after 100 generations of serial growth[3]. Because of high cloning efficiency and easy manipulation of the inserted DNA, the BAC cloning system was proved to facilitate construction of the libraries of rice genome with fuller representation. It has been known that chimeric clones were caused by in vivo homologous recombination and the wrong ligation in vitro. It has been generally believed that about $95 \%$ of the chimeric clones were caused by in vivo recombination and the rest caused by the in vitro wrong ligation. The use of the host cell with high stability of insert, such as DH10 B, should be expected to have very few chimeric clones, although we did not test the recombinant frequency by observation of a positive signal at two distinct chromosomal locations. In addition, we had taken extreme care in choosing the right PFGE conditions and in cutting out the gel slice, so that no small DNA fragments could contaminate the DNA we want to clone in the BAC system.

\section{ACKNOWLEDGMENT}

This work was supported by the Chinese '863' Plan for the Rice Genome Project, and also by the Chinese Academy of Sciences and the Science and Technology Committee of Shanghai municipal government. We would like to thank Dr. Hongbin Zhang for his advice and technical assistance, Ms. Di Yu for her help in preparation of BAC plates.

\section{REFERENCES}

[1] Burke DT, Carle GF, Olson MV. Cloning of large segments of exogenous DNA into yeast by means of artificial chromosome vectors. Science 1987; 236:806. 
Tao QZ et al.

[2] Albertsen HM, Abderrahin H, Cann HM, Dausset J, Paslier DL, and Cohen D. Construction and characterization of yeast artificial chromosome library containing seven haploid human genome equivalents. Proc Natl Acad Sci 1990; 87:4256.

[3] Shizuya H, Birren B, Kin UJ, Mancino V, Slepak T, Tachiir Y and Simon M. Cloning and stable maintenance of 300-kilobase-pair fragment of human DNA in E. coli using an f-factorbased vector. Proc Natl Acad Sci USA 1992; 89:8794.

[4] Wing RA, Rastogi VK, Zhang HB, Paterson AH and Tanksley SD. An improved method of plant megabase DNA isolation in agarose microbeads suitable for physical mapping and YAC cloning. Plant J 1993; 4:893.

[5] Chueng WY, Gale MD. The isolation of high molecular weight DNA from wheat, barely and rye for analysis by pulse-field gel electrophoresis. Plant Mol Biol 1990; 14:881.

[6] Guidet F and Langridge P. Megabase DNA preparation from plant tissue. Methods in Enzymology 1992; 216:3.

[7] Hatano S, Yamaguchi J and Hirai A. The preparation of high-molecular-weight DNA from rice and its analysis by pulse-field gel electrophoresis: Plant Sci 1992; 83:55.

[8] McCormick NK, Antonarakis SE and Herter P.|YAC cloning of DNA embedded in an agarose matrix. GATA 1990; 7:114.

[9] Lerman L and Sinda D. In: E. Lai and B Birren, eds. Electrophoresis of large DNA molecules Cold Spring Harbor Press: Cold Spring Harbor, New York. 1990.

[10] Sambrook J. Fritsch EF and Maniatis T. Molecular cloning. A laboratory manual, 2nd ed. Cold Spring Harbor Laboratory Press. 1989.

[1] Dower E. High efficiency transformation of E. coli by high voltage electroporation. Nucleic Acids Research 1988; 16:6127.

Received 22-7-1994. Revised 6-9-1994. Accepted 12-9-1994. 